\title{
PHILOLOGY
}

\section{THE SUBJECT OF THE QUESTION IN MAONIC SCIENCE AND ITS CLASSIFICATION}

\author{
Mullasodiqova Nigora Miramanovna, \\ Senior Lecturer, \\ International Islamic Academy of Uzbekistan, \\ Department of Arabic Language and Literature, al-Azhar, \\ Uzbekistan, Tashkent city.
}

DOI: https://doi.org/10.31435/rsglobal_sr/31052019/6496

\section{ARTICLE INFO}

Received 23 March 2019

Accepted 10 May 2019

Published 31 May 2019

\section{KEYWORDS}

navh (Arabian grammar), knowledge of adolescence, maanical knowledge, sentence of notification, sentence of notification, sentence of insight, requirement essay, foreign requirement essay, speaker, listener, circumstance.

\begin{abstract}
The topic of the talk and its classification are one of the central issues of syntax. This article compares the classification of the Arabic alphabet with the Arabic and Uzbek linguistic norms. In terms of the stylistics of the Uzbek language, it is explained in terms of how the spelling of the Arabic word begins, and the classification of the Muslim in terms of the context. It is emphasized in Maonic science that the most important aspect of nonspeaking in other languages, especially in the Arabian minority, is the purpose of the speaker and the state of the listener. In Maonical Science there is information on classification in relation to reality, the goal of the speaker and the status of the listener, and in the so-called interpreter, to be a change in reality, and to choose the types of speech.
\end{abstract}

Citation: Mullasodiqova Nigora Miramanovna. (2019) The Subject of the Question in Maonic Science and its Classification. Science Review. 4(21). doi: 10.31435/rsglobal_sr/31052019/6496

Copyright: (C) 2019 Mullasodiqova Nigora Miramanovna. This is an open-access article distributed under the terms of the Creative Commons Attribution License (CC BY). The use, distribution or reproduction in other forums is permitted, provided the original author(s) or licensor are credited and that the original publication in this journal is cited, in accordance with accepted academic practice. No use, distribution or reproduction is permitted which does not comply with these terms.

Sentence and related topics are the most important subject of linguistics. Contemporary Uzbek linguistics is categorized according to its meaning and expression. The stylistics of the Uzbek language are mainly classified as follows [4,151-160]:

1. According to the structure:

A) Simple sentence

-one phrase sentences

-two phrase sentences

B) Combined sentences

-compound sentences

-complex sentences

2. According meaning purpose

- Positive sentence

- Negative sentences

- Question form

The views on the classification of Arabic linguistics are different from those in modern Uzbek linguistics. In the Arabian philology, the classification in the science of science is different from the classification in the science of science. In the science of Nahv, words are classified according to the beginning of the word and are divided into two types: 
1. Named sentence- A sentence that begins with a name, for example

The earth is moving. - الأرض منحركة عن رسول الله: الحسد يأكل الحسنات كما تأكل النار الحطب و الصدقة تطفئ الخطيئة كما تطفئ الماء النار. ( (ابن ماجة، 4200)

From the Messenger of Allah, may Allah bless him and grant him peace, said, "Envy is as good as doing the fire. As charcoal water puts the charity off, sadaqa removes $\sin [1.13]$.

2. Verbal sentence - the sentence that begins with verb. For instance:

The sun rose and the darkness drifted away- أشرقت الثمس وولى الظلام هاربا

He said: "In the heart of a there is either belive or scarcity. قال الرسول الله: لا يجتمع شح و إيمان في قلب رجل

Modern Arabic philologists such as Ahmad Hashimi, Abdulaziz Atiq, as well as the founders of sciences such as Abdulqohir Jurjoniy, Mahmud Zamakhshari, Yusuf Sakkoki, spoke about the subject matter and its classification in the Ma'ani science, the speeches and their usage. In the Ma'ani knowledge, the situation is different from the science of nahv - مقتضى الحال are classified as appropriate. The condition of the condition is mainly determined by two factors:

1. The Purpose of the Speaker.

This is the concept of "expression of purpose" in Uzbek style.

2. The player's position [8.56]

The stereotype of the listener is not taken into account in the classification of the Uzbek stylist. This is a very important factor in Arab science and it is judged in terms of whether the speaker takes into consideration the state of the listener. The nutritional requirements of the speaker should be treated like a physician's attitude toward the patient, so that the physician will have to make a worthy comment, taking into account the condition of the listener, as if he had first diagnosed the patient, identified the condition, and then determined the necessary treatment [8.47]

The speeches are divided into two parts depending on the reality:

1. newsletters

2. إنشائي -insightful words $[8.58 ; 9.164 ; 10.43]$

Anything that can give rise to a question of whether or not it is true or not is a matter of fact. The message is equally true in Uzbek linguistics.

What is meant by relationships rather than realities is called inexplicable statements [9.164]. This description corresponds to the concept of "modality" in Uzbek linguistics. Because modalism is taken into account when dealing with reality. $[3,370]$ The narrative may include phrases, ques- tions, or emotions in Uzbek linguistics.

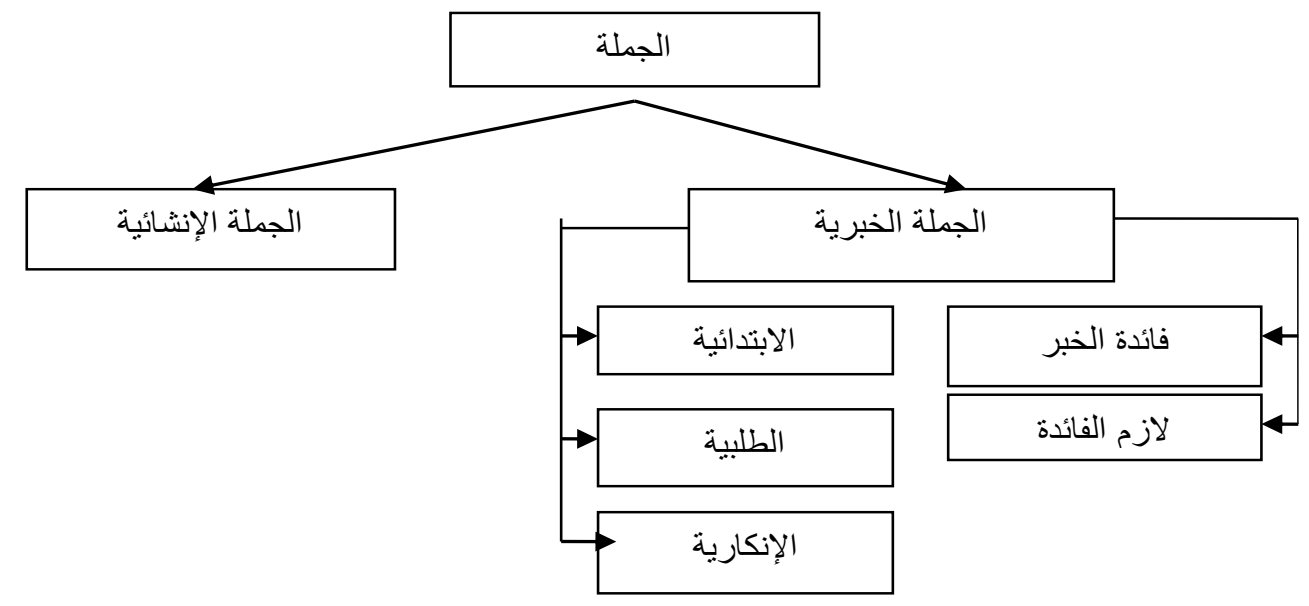

The conversation that related to newsletters is divided into two types depending on the speaker's goal:

1. فائدة الخبر the speaker will give a new message to the listener:

$$
\text { قال رسول الله: عدل ساعة في حكومة خير من عبادة ستين سنة }
$$

The Messenger of Allah (saw) said: "One hour of ruling is better than sixty years of worship."

2. لازم الفائدة - the speaker is aware of the meaning of the word, and the subject of the speaker is to inform him that he is also aware [8.55]:

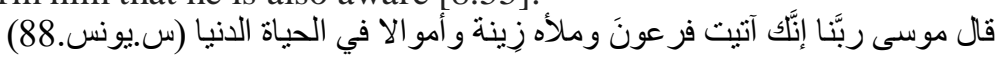

Muso said: "Our Lord! You have given Pharaoh some luxury and wealth in this world. "

The term "expression of purpose" is in the Uzbek linguistics as the requirement of the science of knowledge, not the purpose of the speaker, but the general content of the talk. In the knowledge of abundance the word of the speaker is pillar. 
The translation of the Qur'an verses is based on the translation of the meanings of the Qur'an verses of Abdul-Aziz Mansur the speaker depends on the condition of the listener, the condition is set as a condition. The different content of the messages corresponds to the aesthetic function of the words in the Uzbek linguistics. That is, it can be said that the idea or the idea itself can be expressed intellectually, without any emotions, as well as expressing various emotions - feeling [6. 89]. In the Uzbek linguistics, it is commonly referred to as the expression of intellectual expression, and expressions expressing emotional status are considered as an exclamation point. In making such statements, the speaker must take into account the circumstances of the listener.

If the news is unaware of what the listener is saying, then it is simple, emotional, neutral, and it is in the science of mauni جملة ابتدائية - is called the primitive, first class. For example:

$$
\text { قال علي كرم الله وجهه: مارست كل شيء فغلبته ومارسني الفقر فغلبني }
$$

Ali (Rizali Allah) said: "Why did I cling to myself, but I overcame my poverty and overcome me?"

The listener is aware of the content of the story, but if he is skeptical about its authenticity جملة طلبية demanding, convincing speech should be used. This phrase should definitely be used as a means of expression. For example:

$$
\text { إنا أعطيناك الكوثر (الكوثر:1) }
$$

Mukhammad Verily, we have bestowed on you the Kawthar.

If you are deceived by the listener while being aware of the content, you will need to use two or more prominent tools to convince you that the silence is true جملة إنكارية thake sure that the message is denied "[9. 58-59]. For example:

If you save us from this, we shall certainly be grateful.

$$
\text { لـئن أنجيتنا من هذه لنكوننّ من الثناكرين(يونس:22) }
$$

In addition, subtlety words are divided into two types:

1. Emphasis on essay

2. Emotional Needs In The Construction [10.52]

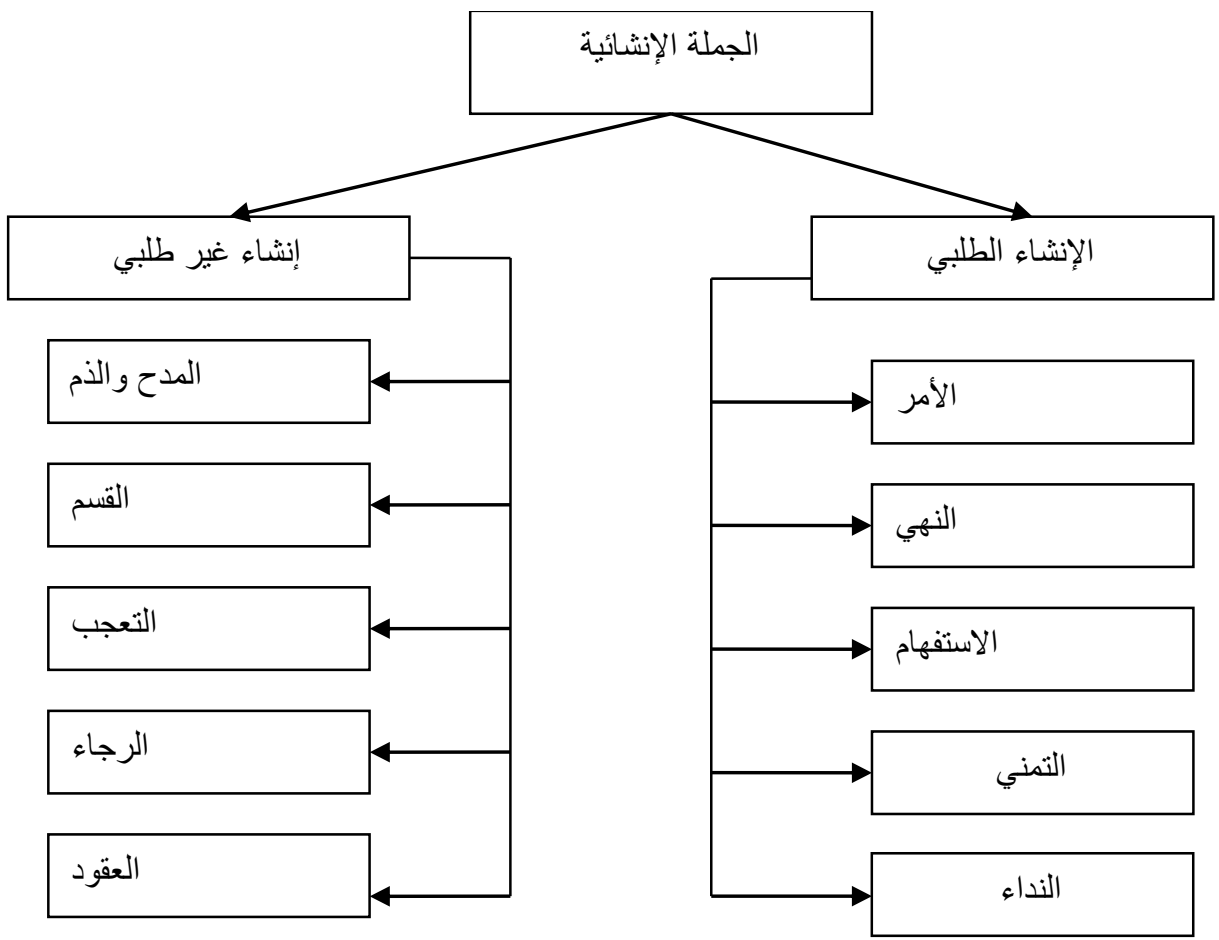

demanding something that requires a change in reality, is called "compulsory tales." This type includes statements that refer to commands, wishes, invitations, and interrogations. For example:

1. Command sentence:

ربنا آتنا في الدنيا حسنة وفي الآخرة حسنة وقنا عذاب النار. (القرآن الكريم: البقرة، 201)

O our Lord! Give us good in this world and good in the Hereafter, and save us from the torment of the Fire.

$$
\text { اعمل لدنياك كأنك تعيش أبدا واعمل لآخرنك كأنلك تموت غدا }
$$

Work for the world as if you were living forever and tomorrow will die for you.

2. Prohibition sentence:

$$
\text { أما اليتيم فلا تقهر. و أما السائل فلا تنهر. و أما بنعمة ربك فحث. (س. الضحى، 9-10-11) }
$$


So do not be cruel with the orphan. Soil (gado) is not a shit! And speak to your Lord of the bounties of your Lord.

3. Question sentence:

أَوَلَيسَ الذي خلق السماو ات والأرض بقادر على أن يخلق مثلهم:بلى وهو الخلاق العليه.(س.يس،81)

Is not He Who created the heavens and the earth able to create the like thereof? Nay, but it is. He is the All-Knowing Creator.

4. Sentence that expresses dream:

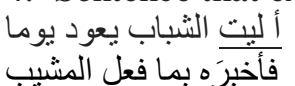

If only one day would come back,

If I say what oldness did

5. Disorder:

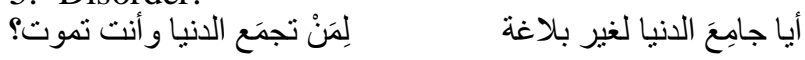

O wealth-doer, you do not understand, To whom will you call it?

- The essay is irrelevant, it does not require a change in reality.

It is a statement of praise or discrimination on such matters (التخاء غيرج) (التعجب), amazing (النجم), oath (الرجاء) as well as emotionally-motivated expressions.

1. Expressions of praise and discrimination:

اعلَموا أنّ الله مو لاكم نِعْمَ المولى ونِعَمَ النصبرُ. (س.الأنفال، 40) Know that Allah is your Protector. How excellent a protector and a helping hand!

هم لكم عدو بئس للظالمين بدلا. (س. الكهف، 50)

They are your enemies! How evil an evil omen for the wrongdoers!

2. Amazing

How can you disbelieve in Allah if you are dead?

كيف تكفرون بالله وكنتم أمو اتا.[8.76]

3. Oath

By God, we are not polytheists

واللهِ رِبِّا ما كنّا مشركين. (س. الأنعام، 23)

4. Imploring

God has given victory ...

In short, the discourse on the requirements of the Arabic and Nasr science requirements is different. In Arabic grammar, the classification is classified according to the beginning of the word, and in the spiritual knowledge it is classified according to the reality. The Uzbek linguistics is categorized according to the structure and expression purpose. The most important factor in the classification of words in the knowledge of the Ma'ani is that of the speaker, and the position of the listener is primary. This figure is not taken into account in the Arabic language. Also, the above two indicators are not taken into account in Uzbek linguistics, particularly in stylistics.

The meaning of the conditions in Arabic science مقضضى الحال as appropriate. The condition of the condition is determined by the purpose of the speaker and the state of the listener. In the classification of the Uzbek stylistic, the requirement of circumstances is not taken into account, but the notion of the speaker's goal is reflected in the concept of "expression of purpose" in Uzbek stylistics. In Uzbek stylistics, the listener does not take into account when making a statement, and in the science of adulthood it is one of the most important indicators, which determines the circumstances of the listener, depending on the state of the listener.

\section{REFERENCES}

1. Abdujabborov A. Human clair Tashkent. 2004

2. Mansurov A. Translation of the Meaning of the Holy Quran Tashkent. 2001

3. Tursunov U. And others. The current Uzbek literary language. T. 1992.

4. Shomaqsudov A. and others. Uzbek stylistics. 1983.

5. National Encyclopedia of Uzbekistan. Tashkent. 2001. Volume 2.

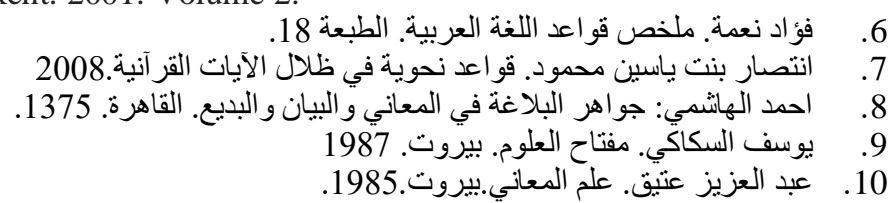

11. Grande. B.M. Kurs arabskoy grammatiki v sravnitelno istoricheskom osveshchenii. M.1998. 